\title{
South African Presbyterian women in leadership in ministry (1973-2018)
}

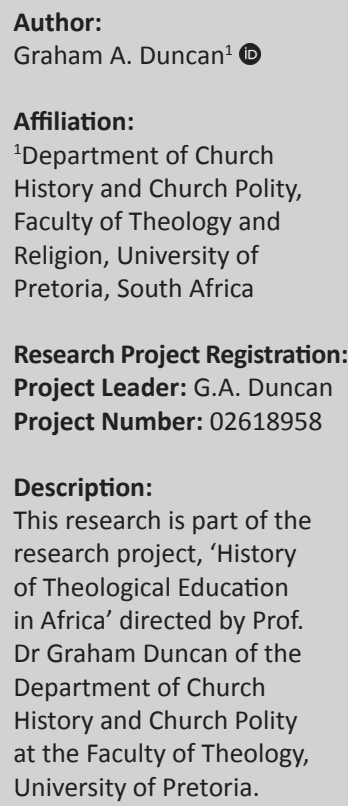

Research Project Registration: Project Leader: G.A. Duncan Project Number: 02618958

Description:

This research is part of the research project, 'History of Theological Education in Africa' directed by Prof. Dr Graham Duncan of the Department of Church History and Church Polity at the Faculty of Theology, University of Pretoria.

Corresponding author: Graham Duncan, graham.duncan@up.ac.za

Dates:

Received: 12 July 2018

Accepted: 02 Nov. 2018

Published: 12 Feb. 2019

How to cite this article: Duncan, G.A., 2019, 'South African Presbyterian women in leadership in ministry (1973-2018)', HTS Teologiese Studies/Theological Studies 75(1), a5180. https://doi.org/ 10.4102/hts.v75i1.5180

\section{Copyright:}

(c) 2019. The Authors. Licensee: AOSIS. This work is licensed under the Creative Commons Attribution License.

Read online:

Scan this QR
code with your
smart phone or
mobile device
to read online.

The issue of women in the ministry has been a vexed one historically. In many denominations, the ordination of women has been represented by some form of struggle, which culminated in the first ordinations of women during the second half of the 20th century. This article investigates the process towards the ordination of women in two Southern African Presbyterian denominations - the Bantu Presbyterian Church of South Africa (renamed the 'Reformed Presbyterian Church in Southern Africa' in 1979) and the Presbyterian Church of South Africa (renamed the 'Presbyterian Church of Southern Africa' in 1958), prior to their union in 1999 to form the Uniting Presbyterian Church in Southern Africa. This article focusses on women in leadership in ministry, not exclusively on women ordained to the ministry of ruling or teaching elder (minister). It begins with an historical overview and proceeds to an investigation of developments in the two relevant denominations. The terms 'leadership' and 'ministry' are used separately and together and are considered to be synonymous. The article uses primary sources from the records of both denominations considered and suggests that the process was gradual and progressive as the worth of women in leadership was recognised following the general acceptance of the biblical and theological arguments.

\section{Introduction}

There are certain issues that disturb the peace and equilibrium of denominations. Many are not of the 'substance of the faith' for 'God alone is Lord of the conscience' (Westminster Confession of Faith $\S X X$ 1645:31). They are adiaphora, inconsequential matters. However, they have the potential to disturb the peace and unity of the church. In a way, this is strange because, women have been integral in the faith community of the church, since the election of God's people and have, in many and various ways, exercised leadership (ministry), though this has often been suppressed in a male-dominated patriarchal environment. While some may consider the ordination of women contrary to scripture, the matter is somewhat outdated and the biblical and theological argument has been won in women's favour as in the case of the denominations under review. It must be noted that ordination to the ministry in the Presbyterian tradition includes the ordination of women to the function of ruling elder, in addition to that of teaching elder (minister of word and sacrament). The main focus of this article is on the teaching eldership, and ordination to the ruling eldership will be discussed where appropriate. There is no attempt here to be exhaustive but to trace developments in a broad sense.

\section{The hermeneutical perspective}

'Leadership in the Christian church has taken different forms at various periods of history' (Purvis 1995:vii) as the church has responded to threats, challenges and contextual circumstances. For instance, during the Reformations, leadership styles changed radically from a hierarchical to a more democratic style. Before there was clear evidence of ordination, the roles of men and women in the life of the church appear to have been fluid. Even when theological and biblical objections were overcome, there remained insuperable barriers to actual ordination (Purvis 1995:viii) as the result of 'white male privileged hegemony' (Purvis 1995:xi). It is not possible to discuss the leadership of women in ministry without taking account of the biblical and historical hermeneutics of women's lack of power and authority in terms of what might be described as conservative evangelical or fundamentalistic hermeneutics, which, to varying degrees, promote the verbal inerrancy of scripture.

Note: The collection entitled 'Christina Landman Festschrift', sub-edited by Wessel Bentley (University of South Africa) and Victor S. Molobi (University of South Africa). 
The enemy here is Christian fundamentalism, which, in the case of the struggle of women to be recognised as partners in ministry, is well described by Purvis (1995) as:

\begin{abstract}
... based on a narrow range of theological and ethical convictions that are not to be subjected to intellectual interrogation from other perspectives. It is the perception that when faith and reason are at odds, which they often are, faith wins, even at the cost of anti-intellectualism. It is the perception that lines of human authority are clear, and ideas and convictions come already interpreted and ready to be put into practice without further reflection. It is the perception, at least, that Christian fundamentalism is triumphalistic, inward-looking, intellectually shallow, inappropriately emotive ... (p. 52)
\end{abstract}

The issue is well articulated as a matter of the authority of scripture by Bellis (1994:16-20). Presbyterian feminist theologian Letty Russell (1985) expressed the dilemma when it comes to interpreting the role of women both biblically and historically:
... the Bible needs to be liberated from its captivity to one-sided white, middle-class, male interpretation. It needs liberation from privatized and spiritualized interpretations that avoid God's concern for justice, human wholeness and ecological responsibility; it needs liberation from abstract doctrinal interpretations that remove the biblical narrative from its concrete social and political context in order to change it into a timeless truth. (p. 12)

This is problematic for patriarchal fundamentalists, who:

\begin{abstract}
... say that the preserve cannot be altered; it must be maintained intact. 'Scripture is fixed; you must not change the text. You cannot make it say what it does not say'. This apodictic protest initiates a second theological reflection. A fixed unchangeable text is neither possible nor desirable. For better or worse, be it conscious or unconscious the text is always being changed. Although translators and interpreters readily acknowledge this truth at some levels, they resist its validity at others. Nevertheless, theological warrant for changing the text lies at the heart of scripture and faith - the name of the Holy One. (Trible 1985:148)
\end{abstract}

Here the issue is the rigid non-negotiable fundamentalist position, which only arose in 19th-century US (Wuthnow 2014:136-140), which was at odds with the teaching and interpretative approach of the 16th-century Reformers who based their interpretation on the hermeneutic of 'let scripture interpret scripture ${ }^{11}$ (Driscoll 2013:1; Uniting Presbyterian Church in Southern Africa [UPCSA] 2007:6:13).

Yet, Russell (1985) affirms inclusivity as integral to her hermeneutic:

There is much to learn about paradigms of authority from communities of oppressed people such as the Black community, whose members listened to the Bible not for doctrinal propositions but for 'experiences which could inspire, convince and lighten'. What is needed is ... the development of new questions and

1.The Bible is a collection of divinely inspired writings written by a number of authors living in different geographical areas in some cases, and written over a long span of history yet it retains an ama history, yet it retains an amazing unity. Because the many voices of scripture make up God's unified revelation, we want to let Scripture interpret Scripture. This involves examining what the Bible has to say on a topic as a whole rather than just picking stray verses here and there and coming to a conclusion (Driscoll 2013:1). paradigms of authority, which are functional in the communities of struggle wrestling with the biblical text. ... liberation is an ongoing process expressed in the already/not yet dynamic of God's action in the New Creation. (p. 17, [italics in original])

\section{Historical overview}

Long before biblical times, patriarchal society made women different and scripture maintained these assumptions, which are still operative in the Roman Catholic and other churches today. However, in the Hebrew Bible, Deborah was a judge, prophet ('a channel of communication between the human and the divine worlds' [Bronner 1994:174]) and woman of 'independent power' in ancient Israel 'teaching and leading the people of Israel in a time of crisis' (Bronner 1994:174) as well as exercising legal, administrative and charismatic military functions (Russell 1985:84). In the New Testament we note the work of many women; the first witnesses of the resurrection of Christ, Prisca (Ac 18:24-26), Lydia (Ac 16:14-15), Phoebe (a deacon, Rm 16:1-2), Mary (Lk 1:46-55), Mary Magdalene (Jn 20:18), Martha (Jn 11:27), Joanna and Susanna (Lk 8:3), Junia, Tryphaena and Tryphosa (Rm 16:121), Julia (Rm 16:13,15), Nympha (Col 4:15), Euodia and Syntyche (Phil 4:2-3) and female prophets were leaders in the New Testament church (1 Cor 11:5), and Philip had four prophetess daughters (Ac 21:9). This despite Paul's injunction against women speaking in church meetings (which was directed at promiscuous women disturbing the worship of the redeemed community; Ac 1:12-14, 18:24-26, 21:7-9, Rm 16:1-16). Yet, Paul acknowledged the role of female prophetesses in Corinth. A far more significant innovation of Paul occurs in Galatians 3:27-28, which relates to the equal status of women and men, all of whom have 'put on' Christ (Corrington 1992:138) and live 'in Christ'. Here Paul broke loose from patriarchal mores as he forged a new Christian paradigm. In the early church no distinctions were drawn in the ordering of ministry. The only qualifications required related to the possession of gifts (special charisms teaching, apostolicity, prophecy, evangelism, pastoral care [Eph 4:11]). Women were elected as deacons (1 Tm 8-13), a position from which they could exercise the right to be heard on matters of the Christian faith' (1 Tm 3:13). Women took up leadership positions in the Early church, for example, Priscilla, Quintilla and Maximilla in the Montanist movement (Corrington 1992:137, 144, 186; Encyclopædia Britannica sa; Jensen 1996:14); many, like Perpetua and Felicitas, were martyrs for their faith (Christian History sa; Corrington 1992:24).

Then women played a largely unacknowledged role in the Reformation, including Jane Grey, Katherina Von Bora, Elizabeth I of England, Marie Dentière, Katharina Schutz Zell and Ursula von Münsterberg (Holcomb 2014:1). Later female leaders included the Methodist Selina, Countess of Huntingdon (Cragg 1960:152). This was a natural outcome of Luther's concept of 'the priesthood of all believers'.

Women (though not ordained) played a significant role in the many 'voluntary' societies that took up the challenge of 
mission before their denominations saw the need to engage in foreign missions. '[V]oluntary' indicated non-alliance with and non-allegiance to the institutional church for the purpose of mission. For Walls (1996:225) it indicated 'a concept that does not inhibit their birth and a style of church organization that is not embarrassed by their activity'. These voluntary societies were free from institutional influence and control. These societies came into being before denominations took up the cause of world mission and 'outflanked and subverted by this novel form of "Protestant association"' (Walls 1996:225), whose membership was open and provided an opportunity for lay leadership including 'women's energies and gifts' (Walls 1996:253). Significant in Scottish mission history is the role played by the Glasgow Missionary Society, which operated from the closing years of the 18th century (Walls 2002:206).

Developments in the Church of Scotland were only a few years in advance of events in South Africa. Recounted in summary, this narrative is instructive:

On Wednesday 22 May 1968, the General Assembly of the Church of Scotland passed a deliverance that women should be eligible for ordination to the Ministry of Word and Sacrament on equal terms with men. The enacting legislation brought to an end decades of campaigning and debate. It opened doors to new opportunities and challenges for women, for congregations and for a ministry which had for centuries been exclusively male. It changed the face of the national church. After the vote, Mary Levison, who had been prominent in the final years of 'wrestling with the church' for recognition of women's vocation to ordained ministry, commented 'the Church no longer regards women as second class citizens. I hope this decision will have a liberating effect right through the Church'. In 1970, Rev Dr Ian Fraser, during a seminar on the ordination of women, asked some still pertinent questions: 'Add a few ordained women to an unreformed ordained ministry and how much further forward are you? ... all that you have is a face-saving operation. You fail to deal with that godly dissidence and frustration which belong, to my mind, to the Holy Spirit's pressure to reform radically church institutions. It is when the question of the ordination of women is seen in its total context of reinheriting the whole people of God, and then seen as a dimension of the quest for the reinheriting of the whole of humanity'. (CTPI 2018:1)

Reid is commenting on the recognition of women within their new role rather than the acceptance of the Spirit's challenge to use it as a transforming dynamo within the traditional church institution.

Within the African context, we note the contributions made inter alia by Kimpa Vita (Donna Beatrice), Alice Lenshina, Mai Chaza, Gaudencia Aoko and Mwilu Marie Kimbangu (Daneel 1987:59). In South Africa similar contributions were made by Ma Nku (Daneel 1987:59), Charlotte Maxeke (Millard 1999:39-41) and Vehettge Magdalena Tikhuie (Millard 1999:69-72). All of these aforementioned women were people of independent spirit.

We now turn to the role of women in the South African Presbyterian churches.

\section{Dr Jane Waterston: Prototype Presbyterian woman in leadership}

Jane Waterston (1843-1932) is significant for this study as she was a prototype leader in women's ministry, though never ordained. She arrived at Lovedale as a missionary of the Free Church of Scotland in 1866, and in 1868 'opened a girls' boarding school with her own vigorous and original personality' (Shepherd 1971:28). This was the beginning of her strong advocacy for the higher education of women (Bean \& Van Heyningen 1983:279-287). In 1880 after having qualified as a medical doctor, she opened a medical department at Lovedale Missionary Institution (Shepherd 1971:43) and ran both departments concurrently until 1883 (Shepherd 1971:28, 34, 107, 151,157). In 1879, Waterston went to Livingstonia in Nyasaland (Malawi), but she soon returned to Lovedale having failed to find the degree of acceptance as a woman that would facilitate God's missionary purpose. From 1883, she practised medicine in Cape Town, where she lived until her death in 1932. On moving to Cape Town, she left the Scottish mission and joined St Andrew's congregation, which became the mother church of the Presbyterian Church of South Africa (formed in 1897). Hence, she bridged the gap between the two Scottish branches of South African Presbyterianism. Van Zyl (1985:6) has aptly described her as 'a remarkable woman intelligent, courageous, determined, full of energy and committed to serving the Lord'. Bean and van Heyningen (1983:12) refer to her 'competence [and] ... strength of character' as well as her 'rare determination, courage and intelligence' (Bean \& van Heyningen 1983:11). Waterston made an important contribution to feminist, medical and social development. Together these are significant qualities in the exercise of women's leadership in ministry as they empowered her to persevere in the face of obstacles.

Many other women, black and white, though less dynamic in personality than Waterston, followed in her footsteps and made significant contributions to God's mission in South Africa.

\section{Bantu Presbyterian Church of South Africa}

One of the ecumenical issues raised by Murray (Presbyterian Church of Southern Africa [PCSA] minister 1973:11) is that 'the BPC (Bantu Presbyterian Church of South Africa) would strongly oppose the ordination of women'. This was patently untrue as subsequent events revealed, although the ordination of women to the eldership is said, from the perspective of 25 years later, to have occurred 'only after a heated debate' (UPCSA 2001:119). From the perspective of the later Gender Issues Committee of the UPCSA, Reformed Presbyterian Church of South Africa (RPCSA) proposals for equity in Presbytery were 'in advance of anything proposed in the PCSA. ... Unfortunately, however, the rule has not been carried over into the UPCSA, which has thus fallen back from it' (UPCSA 2001:119). 
Charity Majiza was the first woman to be ordained in the Bantu Presbyterian Church of South Africa (BPCSA). She was born in Burnshill but grew up in Zwelitsha, and while she was a member at Semple Memorial Congregation in the Presbytery of the Ciskei she applied to become a candidate for the ministry. Her candidature was somewhat of a test case as she went to the Federal Theological Seminary of Southern Africa before any decision had been made or was even considered regarding women's ordination. She graduated with a Diploma in Theology (with Greek) from the Federal Theological Seminary. The Presbytery of the Ciskei was censured by the General Assembly for proceeding to promote her while there was no provision for the training and ordination of women. Further, she was allowed to remain in training while the General Assembly sent the matter of the ordination of women down to presbyteries under the Barrier Act (BPCSA 1975:43). The purpose of this act (adopted from the Church of Scotland 1697; Cox 1976:385) was to prevent the denomination from making hasty and/or far-reaching changes to church law without due consideration and consultation. In the same assembly, the ordination of women as deacons was approved and that of women as elders sent down to presbyteries under the Barrier Act for discussion.

At the 1976 General Assembly, Majiza's name was forwarded to the Church Extension and Aid Committee for appointment on successful completion of her qualification (BPCSA 1976:23). The matter of the ordination of women elders was also raised at this time and the assembly failed to reach a definitive position. Yet the matter of the training of women as ministers was remitted to presbyteries along with a Training for the Ministry Memorandum on the Admission of Women into the Ministry. In 1977, the BPCSA General Assembly took the momentous decision to 'admit women to the offices of elder and minister having the same status as men' (BPCSA 1977:28).

Majiza was licensed by the Presbytery of the Ciskei on 08 January 1978 (BPCSA 1978:17), was sent to do her probationary period in Gooldville congregation in Venda and was ordained on 13 May 1978 (BPCSA 1978:17). Venda was often the destination of candidates for the ministry who had challenged the system. However, she did particularly well there in a brief but faithful ministry and was sent to Scotland in September 1980 (RPCSA 1980:24). She completed the Honours degree of Bachelor of Divinity in Practical Theology in 1983 (RPCSA 1983:28, 39) and the Master of Theology Degree in Missiology in 1984 (RPCSA 1979:20, 1980:24, ${ }^{2}$ 1983:38). While there she, with another BPCSA minister, Rev. Cliff Leeuw, was threatened by agents of the South African Special Branch (RPCSA 1984:40) regarding statements made at public church meetings. Subsequently, she moved to Australia in 1984, apparently for security reasons, where she pursued her ministry (RPCSA 1984:40, 1985:38-39). Leeuw confirmed 'Rev Majiza's fear for her life and her family's safety' (RPCSA 1984:40). The General Assembly investigated the circumstances of Rev. Majiza'a irregular (i.e. without consultation with the RPCSA) departure to Australia but with little immediate success. The source of the harassment was clearly related to South Africa's apartheid policy, against which Scotland's anti-apartheid movement and the Church of Scotland had taken a clear stance. Missionaries on leave and students from South Africa were expected to speak at meetings on this issue and this included Majiza, who was clear in her anti-apartheid position.

For a time, Majiza returned to South Africa with her husband, Graeme McKinty, who initiated HIV/AIDS support groups in a variety of churches that were sympathetic to those who were living with the condition. She was appointed General Secretary of the South Council of Churches in 1998 and was the first ordained woman to hold this position. Concurrently, she was reinstated as a minister of the RPCSA. In 2002, she was appointed a minister in association at St Columba's Parkview (UPCSA 2002:22). Following this, they returned to Australia where she has exercised a faithful ministry at Echuca Moama Uniting Church, in Australia.

Majiza's ordination facilitated the progress of women's ministry in the BPCSA. The next candidate, Snowy Maomosi, graduated from Fedsem with a Diploma in Theology in 1979 (RPCSA 1980:170) but did not proceed to ministry.

The next two female candidates were Thokozani Mildred Ngcongo and Nokhalipa Vivienne Nonjojo, who completed their studies at Fedsem in 1988 and were placed in congregations. Ngcongo served her entire ministry at Ugie congregation in Unthatha Presbytery until her death in 2015. Nonjojo served at Maclay congregation in Transkei Presbytery (RPCSA 1988:36) until her resignation in 1998 (RPCSA 1998:54). In 2004 she became a chaplain in the South African Defence Force (UPCSA 2004:113), as have a number of others since.

A problematic situation arose in 1995 as the result of the presence of Rev. Sarah Holben from the Presbyterian Church of the USA (PCUSA). Ms Holben had been recruited by Rev. S.P. Xapile to assist in his HIV / AIDS project, during a trip to the USA. Holben had been introduced into the Reformed Presbyterian Church in Southern Africa (RPC) irregularly as an 'assistant pastor' (RPCSA 1995:17). A committee was established to investigate the partnership that existed between Xapile's congregation (J.L. Zwane) and the PCUSA (Presbyterian Church of the United States of America) (RPCSA 1995:3). The remit of the committee was later extended to include Holben's husband, Mr Robert Schminkey, who was recognised 'as a representative of the PC [USA]' (BPCSA 1995:65). In the following year, it was noted that Holben's term of office would expire at the end of the year (RPCSA 1996:76). The growth of partnerships between congregations of the RPCSA and US congregations was formalised in 1997 when the General Assembly agreed 'that the Ecumenical Relations committee coordinate and oversees all partnerships in our church' (RPCSA 1997:53). 
The next application from a woman came in 1997 from Ms Bulelwa Ngebulana (RPCSA 1997:44). In 1999, Mrs Seani Mavhina (RPCSA 1999:20) was accepted as a candidate for the ministry. Several other women were referred to the Ministry Committee for consideration but none of them proceeded any further.

A matter that was significant in the decision to ordain women was 'the crying need for candidates for the Ministry' in 1976 (BPCSA 1976:18). At that time only 47 out of 78 congregations had ministers (BPCSA 1976:2-9). Nonetheless, the decision to ordain women was a courageous step for a conservative black denomination with a strong patriarchal tradition. In a sense, although the ordination of women resulted from an attempt to hijack the system by the Presbytery of the Ciskei, once the initial irritation was over, the acceptance of women was easily integrated into the ecclesiastical system. Although the growth of numbers of women in ministry was slow to begin with, numbers have increased progressively and women have become part of the accepted structure of the ministry of the BPCSA.

\section{Presbyterian Church of South Africa}

The PCSA first approved the ordination of women to the ruling eldership in 1966-1967 'only after a heated debate' (UPCSA 2001:119) and to the ministry (teaching eldership) in 1975 (Bax 1997:19). 'However, a minority of ministers and elders from the old PCSA still oppose women being elected as elders' (UPCSA 2001:119). This matter originated in an overture from the Presbytery of the Transvaal. The Ministry Committee examined the matter and 'felt in no way under pressure from current "Women's Liberation" thinking' (PCSA 1972:78; cf. Murray 1973:1). This would suggest that either there was some suggestion of pressure from feminists or that this was a concession to the theologically conservative element in the denomination. Three papers had been commissioned from Mrs P. Tittlestad (University of South Africa [UNISA]) and the Revs. John Hawkridge and Duncan Murray (only Murray's paper was available to the author). It is noteworthy that no black person was requested to submit a paper considering differences in culture. All ministers and a number of elders received the documents for consideration. Then the committee consulted a number of women who had made their mark in their own fields in South African society. Rev. Frances McLellan, former president of the United Church of Canada, was also consulted. Several points of interest emerged. There was no shortage of ministers that caused pressure to ordain women. The predominant feeling was that the call of women should be subjected to the same process of discernment as that of men. Family commitment was not determinative. McLellan's view was substantive:

To men, I can only say that to deny women the right to answer this call, if it comes, is surely to deny our whole Christian teaching about the value of persons in God's sight. (PCSA 1973:vii.1:78)

As with the issue of feminism, Murray's paper is suggestive of existing tensions in the PCSA at the time. A conclusion he reached was as follows (Murray 1973):
We must not refuse to ordain women to the ministry for the sake of a particular principle of interpreting Scripture - thinking here of principles of interpretation that lean towards the literal side. (p. 5)

Whatever reasons might be promoted against the ordination, the General Assembly was clear:

The Assembly finds no biblical or theological reason for denying women ordination to the Holy Ministry, and rules that women be eligible for ordination. (PCSA 1973:133)

The matter was remitted to presbyteries for responses to be submitted by 30 April 1975. In 1975, following receipt of returns from Presbyteries an amended proposal was agreed that:

The Assembly approves the ordination of women to the Holy Ministry but only ordains on receipt of a call by a congregation at the conclusion of the Post Academic Training period. (PCSA 1975:123)

There were 10 expressions of dissent but the decision was decisive.

\section{The Ministry Committee had earlier noted that:}

Mrs E[thnie] Fourie completes her final BD at the end of this year and, if Assembly decided to admit women to the Ministry, has indicated her intention to seek Ordination. (PCSA 1975:40)

She was ordained on 30 January 1976. Ethnie Fourie exercised a remarkable ministry in the 10 -year period before her death in 1986. In the Kroonstad congregation from 1977 she concentrated on early childhood and prison ministry in addition to her congregational responsibilities, which she executed with 'fervour and dedication' (PCSA 1987:C6).

Also, in 1975, it was noted that Mrs Margaret Donaldson (a minister's wife) had been appointed a junior lecturer in the Department of Ecclesiastical History in the Faculty of Divinity at Rhodes University (PCSA 1975:40; Donaldson 1990:7). Though not a minister herself, she made a substantial contribution to the training of ministers.

However, matters did not end there, for a Committee in the Role of Women in the Church was formed to continue discussions on the topic. It made its final report in 1983 (PCSA 1983:115-122, 210, 246) on the theme:
The woman's cause is man's; they rise or sink Together, dwarf'd or god-like, bond or free. (The Princess, Alfred Tennyson, 1847)

Valerie Thomson, wife of Rev. Ian Thomson, studied for the Diploma in Theology at the Federal Theological Seminary (as did Sandra Duncan, wife of Rev. Graham Duncan, of the RPCSA). Both studied during the 1970s and 1980s and both graduated with distinction. Neither chose to offer for ordination. In 1980, Diane Vorster, a trained and experienced nurse, was placed on probation at St Andrew's, Benoni having completed her BD degree successfully at 
Edinburgh University. Jean Carr was the second woman minister in the PCSA. After training for the ministry in her late forties, she was ordained and served congregations including Parktown North, Klerksdorp, from 1991 to 1998, then at Eshowe. She died in 2009 (UPCSA 2010:10).

Rev. Pat Baxter was trained as a candidate of the PCSA and was seconded to the PCUSA in 1984 to pursue further studies (MA and DMin) in the fields of Christian education, pastoral care and spirituality (PCSA 1999:43). She also worked at St Columba's, Parkview, beginning in 1987 (PCSA 1987:C5; Editor 1987:6) and again from 01 January 1990 (PCSA 1990:C9), and later at St Columba's, Pretoria (PCSA 1990:C10). She finally returned to South Africa in 2010. After serving briefly in two congregations, she was called to be Ministry Secretary of the UPCSA and the first woman to hold a senior executive post in the denomination.

Rev. Jane Nyirongo was the first Zambian and the first woman from the transnational presbyteries in Zambia and Zimbabwe to be ordained in 1991 (PCSA 1991:C7). In 2004, she was seconded to the Cheshire, Flint and Denbigh Presbytery of the Presbyterian church in Wales as Mission Advisor for 3 years' (UPCSA 2004:415). Nyirongo was followed a year later by Sulani Kabala (PCSA 1992:C8), whose husband, Petson, was also ordained a minister in Zambia. Jennifer Mutemi (husband, Rev. Charles Mutemi), later Jennifer Handitye, was the first woman minister to be ordained in Zimbabwe (PCSA 1999:229). She died in 2015 (UPCSA 2016:22).

A further innovation occurred in 1992 when Pauline Sparks trained for the ministry and worked alongside her husband, Terry, both in Upper Umgeni in South Africa and the United Kingdom at Twickenham and Hampton Hill congregation of the United Reformed Church (Editor 1992a:5; UPCSA 2005:168).

During this entire period, the growth of women as ruling elders has been exponential in both denominations while admission to the ministry has seen a far slower process of growth.

\section{Uniting Presbyterian Church in Southern Africa}

When the union that led to the formation of the UPCSA took place in 1999, both uniting denominations had been ordaining women for over 20 years. A further step in securing and promoting the place of women was taken in 1994, which was engrossed in the Manual of Faith and Order (UPCSA 2007:25), which stated explicitly that no one may be barred from any office in the church on the grounds of race, youth or gender: 'God calls both men and women to every office in the Church' (UPCSA 2007:25). This was an updating of a PCSA General Assembly decision of 1980 motivated by Rev. Ethnie Fourie in the report of the Committee on Women in the Church:
The General Assembly instructs all Sessions that it is contrary to the will of this Church to discriminate against any persons on grounds of sex (colour etc.) and reminds Sessions that suitably qualified women and not only men be sought out and instructed in the work of eldership and policy of the Church. (PCSA 1980:193)

The Confession of Faith (UPCSA 2007:2.4-2.37) was explicit in its view that:

[t]he church is the family of God. All people born of the spirit are children of the one Father and so brothers and sisters of Christ and of one another. (UPCSA 2007:2.23)

and ' $[n]$ o member of the body can reject any other; for God has accepted us all in the beloved Son and bound us together in one spirit, as members who need one another for the body to function properly in its work and witness to the world' (UPCSA 2007:2.23).

Rev. Diane Vorster (BD, MTh) was the second person and the first Presbyterian woman to be elected moderator of the General Assembly of any Presbyterian Church in Southern Africa in 2000 (PCSA 1999:15), following the union of the PCSA and the RPCSA in 1999 to form the UPCSA. She was described as a 'person of strong convictions and deep spirituality' with 'an evangelical and ecumenical heart. ... gentleness and strength' (PCSA 1999:15).

Rev. Glynnis Goynes, whose first charge was as minister at Saints congregation in the Presbytery of Tshwane, retired in 2017 after being seconded to a parachurch organisation, South African Faith Communities Environment Institute, as operations manager in 2011 (Minutes, Presbytery of Tshwane, 14 May 2011:3, 8-9, 15-16).

General Assembly committee convenerships were opened to women, all of whom happened to be laypersons: Valerie Thomson (Life Concerns), Nomthandazo Mbo (Gender Issues) and Mavis Dewar (Congregational Integration).

\section{Gender in the Uniting Presbyterian Church in Southern Africa}

A Gender Issues committee was established by the inaugural General Assembly of the UPCSA in 1999 (PCSA 1999:40). Despite the advances made in recognition of the role of women in leadership in the South African Presbyterian tradition, there was still resistance to the recognition and promotion of women within the new uniting denomination. This was, however, a universal issue related to the goals and tasks of the committee. The historic fact was stated by the Council for World Mission:

Although women form the majority of membership in most of our churches, they are poorly represented in leadership positions. They are often discriminated against and their voice is rarely heard. (CWM 1999:11; UPCSA 2000:138)

The committee's proposals related to the definitive representation of women, youth and all regardless of race (UPCSA 2002:361). 'Women Leaders in the Church', 
a document produced by the Gender Issues Committee in 2000 (UPCSA 2000:140-152), provided a helpful appendix to the committee's report to the General Assembly in 2000 (UPCSA 2000:140-152). This was an indication that despite the advances made in the role of women in leadership within the church, there still existed a body of opinion that opposed women in ministry. This was largely related to a group within the denomination who pursued a conservative evangelical, literalist or fundamentalist hermeneutic of scripture. This has been a recurrent issue in the UPCSA, where issues (earlier described as adiophora) are raised when the substantive issue common to all is the authority of scripture. The UPCSA stands firmly within the Reforming tradition and its Confession of Faith. The ordination vows for ministers are clear:

I accept the Scriptures of the Old and New Testaments as inspired by the Holy Spirit to be the uniquely authoritative and sufficient witness to Jesus Christ and as such the Word of God and the final rule of faith and life. (UPCSA 2007:2:34)

The General Assembly has never imposed a particular hermeneutic on its ministers or members. Following the Westminster Confession of Faith (Church of Scotland 1969:31) where it is declared: 'God alone is Lord of the conscience', 'the Uniting Presbyterian Church in Southern Africa ... maintains liberty of conscience and of worship, within the rule of Scripture, of all members of the one holy catholic Church' (UPCSA 2007:1.1).

The paper 'Women Leaders in the Church' focussed on the gender of God (UPCSA 2000:140-141) and women leaders in the Bible (UPCSA 2000:141-152). The evidence for the leadership of women in ministry in both the Old and New Testaments is substantial: '... the Bible does provide for female leaders in both the political and religious community' (UPCSA 2000:141). The traditional arguments against the role of women (Christ was male and chose only males) are challenged strongly (UPCSA 2000:142-152). The report quotes Schrage (1988):

Paul ... speaks of women as fellow workers and companions (Rom 16:3; Phil 4:3), even acknowledging women who hold the office of apostle (Rom 16:7). Above all, Paul refuses to forbid women to prophesy, as 1Cor 11:5 clearly shows. (p. 223)

A further boost is given to the equality of women in consideration of the Galatians 3:26-29 text, 'the first occurrence of a doctrine openly propagating the abolition of sex distinctions' (Betz 1979:190, 195, 197). Interestingly, conservative evangelicals underemphasise the universalistic nature of Paul's teaching here and miss the point that ' $[n]$ owhere ... does he subordinate women to men' (UPCSA 2000:149).

In sum, 'Women Leaders in the Church' concludes, inter alia, that Jesus 'attitude to women was revolutionary' and notes that:

... as the Resurrected Lord he revealed himself to his women disciples first and sent them to tell the news to the other disciples, so that the women were the first 'apostles' to be 'sent' with the 'gospel of the resurrection'. (UPCSA 2000:152)
The occasion for the 2002 report, following on the extensive 2000 report, was in part the failure of the assembly to pass two proposals in the 2001 Assembly relating to the role of women in leadership in the councils of the denomination. It pleaded for:

gender democracy, if we genuinely want to implement the biblical principle that there is no distinction in spiritual privilege or status between Jew and Gentile, slave and free, male and female. (Gl 3:26-28)

This report focussed on the devaluation of women in an appendix, 'The War against Women' (UPCSA 2002:263-272). It argued from a biblical, theological and historical perspective that women had been discriminated against politically, legally, economically and domestically in all of the religions of the book - Judaism, Christianity and Islam (UPCSA 2002:363-364). Following sections on the gender of God, the role of the Fall, the understanding of God as a matrix and the culpability of Eve, the paper ends with a section on Jesus who never made a negative statement regarding women, did not marginalise women, treated them with dignity and respect and 'brought to an end the inferior status of women' (Schrage 1988:91):

But quite contrary to rabbinic custom, he included women in his travelling entourage as female disciples and unashamedly depended on the financial generosity of women to fund his mission. (Mk 15:40f.; Lk 8:1-3)

In relation to the gender of God and our faith, the conclusion of the report offers guidance for a way forward:

The Christian faith and life is not a matter of believing ideas so much as it is living in this intimate relationship with God that is best described in the metaphor of God's being Father and Mother to us 'as a father has compassion for his children, so the LORD has compassion' (Ps 103:13). 'As a mother comforts her child so I will comfort you (says the LORD)' (Isa 66:13). If Christianity is not to be sexist, its preachers and theologians must emphasize both sides of this parental metaphor. They must oppose sexism clearly and emphatically in others and in themselves, including the way they use words for God. (UPCSA 2002:373)

The General Assembly received these reports and commended them for study in presbyteries and congregations.

The first female minister to enter academic life in South Africa is Rev. Fundiswa Kobo, who studied at the universities of Forth Hare and Pretoria, where she is presently studying for her doctorate. She is on the staff of the Department of Church History, Christian Spirituality and Missiology at UNISA. She is associated with the ministry at St Andrew's, Pretoria. She has made her position absolutely clear on her ministerial identity from a womanist perspective (Kobo 2018a:1):

I am not a female or a woman minister, nor am I a minister's wife (mme moruti or mam ruti, mama mfundisi, mfundisikazi). I am an ordained minister!!! Mfundisi, umlomo ugcwale! Siyevana bantase. (Fundiswa Kobo, Facebook post, 23 August 2018b) 
Her (Kobo 2018a) own recent experience is instructive:

I was sent by the UPCSA as one of the delegates to a consultation of Reformed churches in the Southern Africa Region whose aim was to establish themselves as a subregion of the Africa Communion of Reformed Churches, an African region of the World Communion of Reformed Churches. It was held in Emseni Conference Centre, in Benoni, from 22 to 24 March 2018. The delegation was comprised of moderators and general secretaries of these churches, who were all men, except for a few women who were requested to be 'administrators'. I was also requested to be one and refused as a form of protest. (p. 6)

However, it would be true to say that, at the time of writing, the issue of gender remains an issue. This became apparent at the General Assembly of 2018, when a paper was submitted from the Women's Consultation at the 13th General Assembly of the UPCSA - July 2018. This arose out of a consultation on women in ministry held at Lumko in March 2015. It highlighted a number of issues:

- few women in the upper leadership roles of the denomination

- we are not 'female ministers or elders', but ministers who are women and elders who are women

- many women still stuck in traditional or cultural mindsets.

This led to the formation of a vision statement: We are 'a united body of Christ that is repentant, reconciled, respectful and discerning of the will of God - whilst actively addressing gender equality at all levels' (Women's Consultation 2018).

Kobo interrogates assumptions that there are spaces where women exercise their own autonomy. This is the place where the iimanyano [women's association] meets: 'These are supposedly women's spaces because it is only women who gather together with the agenda supposedly formulated by "them". Some practices, nonetheless, contradict this' (Kobo 2018a:4-5). She believes that even in these spaces women are captive to patriarchal values.

A further problematic development took place in 2018 when the General Secretary sent a letter to the women ministers in the UPCSA requesting their participation in a celebration of 40 years of women in the ministry:

This was received with mixed emotions by women themselves as we engaged through text messages, phone calls and emails. Some of the questions raised by different women are: who is inviting? Who is being invited? Who said we want to celebrate? Why we were not consulted? Why do they speak on our behalf? Why do they invite us to celebrate when we have congregations that will never call ordained women to be their ministers? Why must we celebrate in a church that clearly does not want us? (Kobo 2018a:5)

Rev. Charity Majiza was invited to be the guest speaker on this occasion and Kobo (2018a:6) trenchantly commented: 'her invitation however is an illustration of the co-optation of women in the agenda that is not theirs'. However, Majiza was under no illusion regarding the role of women. She saw her purpose as: to celebrate the good that has happened, to lament and confess our failures, to receive forgiveness, to heal and to be reconciled to one another before God, in order to be able to move forward together with confidence in the mission to which God has called us, both women and men in the Church. (p. 6)

Majiza (2018:4) raised a number of significant points:

- The UPCSA is not where it had hoped to be on this 40th anniversary of the women in the ordained ministry.

- While some women have succeeded and flourished in the ministry in spite of challenges, with the help of those around them, the same cannot be said of others.

- Other women ministers have experienced lots of hurt, lack of support, disrespect and not seen as equals with their male colleagues at various points during these 40 years.

- There is a gap between the leadership's commitment to promoting the ministry of women and the practice some women ministers experience at the local churches and within the church structures, which has hindered their advancement in the ordained ministry.

- The current status perpetuates injustice against women and deprives the church of their unique gifts and quality of leadership.

- This, in a subtle way, thwarts the vision and efforts of the church to promote women into senior leadership positions.

This was an insightful comment for someone who had not participated in the life of the UPCSA for a number of years. Towards the close of her address, Majiza (2018) postulated a vision for the UPCSA:

First, the aspirations of the Church for, 'equity and justice in the ministry and women being considered for senior leadership positions in the Church' can be realized.

Second, the Church can be empowered to speak with authority and credibility to the society on issues of disrespect, injustice, inequality, dehumanization, domestic abuse and on violence against women outside the home.

Third, the Church can become an instrument of healing and reconciliation and her commitment to work towards the 'fullness of life' for all, will be there for all to see in the community. (p. 7)

This was a prophetic address that was a source of encouragement for all in the UPCSA to work towards becoming a fully inclusive church, 'a priesthood of all believers'. It was an authentic statement of the present, yet not fully present, status of women in the ministry of the UPCSA.

\section{Evaluation}

Zikmund competently expresses the experience of most church members regarding ordained women ministers in the US that women appear to integrate seamlessly into the existing discourse without disrupting it, yet they unobtrusively promote their cause by the excellence of their commitment and service. 
These women pastors do what people expect them to do as women and as pastors. They do not deny the conventional expectations people have of them as women, and they do not disrupt conventional wisdom about the power and authority of effective pastoral leadership. They live comfortably with both, even though a 'feminine female is supposed to be commensurate with, if not oppositional to, strong organisational and political leadership abilities. By embodying roles our social scripts say cannot be played by one person and roles that involve socialization processes that may be contradictory' (referring to Jacquet 1978, 1989), they actually profoundly challenge unexamined assumptions about both women and clergy. In short, they are the best 'men' for the job and they are women (Zikmund 1995:xi-xii).

However, Zikmund's assessment rings true also within the South African Presbyterian system:

\begin{abstract}
... their leadership styles cannot be characterized along the lines of gender expectations, and yet, what they exceptionally are is conventional. They transgress neither vocational roles not gender; they fulfil both. The combination is transgressive. (Purvis 1995:85)
\end{abstract}

This combination crosses boundaries. By and large, the leadership of women ministers is not based on gender expectations. It is exceptionally conventional. The experience of having women in leadership in South African Presbyterianism is a positive one. The excellence of their faithfulness, responsibility and service is unchallenged. Once the ordination issue was resolved, they have simply got on with the job and pursued their calling, and by the quality of their service they have demonstrated the wisdom of the General Assembly in permitting them to be ordained.

The fear, expressed in Murray's (1973:10) paper, that women would 'take over and completely feminise the institution' has not happened in the SA context, nor in any other case globally. However, we may concur with Purvis (1995) assessment as a future prospective in the South African context regarding the embodiment by female pastors of traditional roles in ways that challenge tradition and are transgressive of gender expectations who:

are part of a quiet revolution. They are not espousing or practicing radical social change; ... On the other hand, selfconsciously or no, ... women ... are not simply reinscribing patriarchal power and control. The transgressive role of traditional roles here is a subtle and effective agent of change. The ability ... to live in the midst of incommensurate discourses and to continue to function so effectively in all of them, hold forth the promise of new discourses, even with some of the same old vocabulary. (pp. 96-97)

While this may be true for the most part, it is not universally held truth.

\section{Conclusion}

The experience of having women in leadership in ministry in South African Presbyterianism has been a positive one at all levels of the denominations involved. Now women are rarely referred to separately in terms of leadership in ministry. This has been a story of progressive integration as leadership was expanded and developed to all aspects of the denomination's lives despite some resistance and outdated patriarchal attitudes and actions. An integrated ministry has served the church well and will continue to do so into the future despite the challenges that are still prevalent. The experience of women in the UPCSA, as opposed to the experience of the denomination and its members, which is generally positive, is mixed with some having serious reservations regarding the authenticity and integrity of their role. For them a luta continua!

\section{Acknowledgements Competing interests}

The author declares that he has no financial or personal relationships that may have inappropriately influenced him in writing this article.

\section{References}

Bantu Presbyterian Church of South Africa (BPCSA), 1975, 1976, 1977, 1978, 1979 1980, 1984, 1988, 1995, 1996, 1997, Proceedings of General Assembly, BPCSA Umtata.

Bax, D.S., 1997, The Presbyterian Church of Southern Africa, PCSA, Johannesburg.

Bean, L. \& van Heyningen, E. (ed.), 1983, The letters of Jane Elizabeth Waterson, 1866-1905, Van Riekeeck Society, Cape Town.

Bellis, A.O., 1994, Helpmates, harlots \& heroes: Women's stories in the Hebrew Bible, Westminster/John Knox Press, Louisville, KY.

Betz, 1979, Galatians, Fortress, Philadelphia, PA.

Bronner, L.L., 1994, From Eve to Esther: Rabbinic reconstructions of biblical women, Westminster John Knox Press, Louisville, KY.

Christian History, sa. Perpetua: High society believer, viewed 05 March 2018, from http://www.christianitytoday.com/history/people/martyrs/perpetua.html

Corrington, G.P., 1992, Her image of salvation: Female saviors and formative Christianity, Westminster Press, Louisville, KY.

Centre for Theology and Public Issues and New College, University of Edinburgh (CTPI), 2018, Commemorating 50 years of women's ordination in the Church of Scotland, viewed 14 March 2018, from https://www.eventbrite.com/e/commemorating-50gods-tickets-44019330001?utm_source=eb_email\&utm_medium=email\&utm gods-tickets-44019330001?utm_source=eb_email\&utm_medium=email\&utm
campaign=order_confirmation_email\&utm_term $=$ eventname\&ref=eemailordconf

Church of Scotland, 1969, Westminster Confession of Faith (1647), Blackwood, Edinburgh.

Council for World Mission (CWM), 1999, Inside Out, CWM, London, vol. 9, p. 11.

Cox, J.T., 1976, Practice and procedure in the Church of Scotland, The Committee on General Administration, Church of Scotland, Edinburgh.

Cragg, G.R., 1960, The Church and the Age of Reason, 1648-1789, Penguin, Harmondsworth.

Daneel, M.L., 1987, Quest for Belonging: Introduction to a study on African Independent Churches, Mambo Press, Gweru.

Donaldson, M., 1990, 'History matters', Presbyterian Life, 07 April, p. 3.

Driscoll, M., 2013, Let scripture interpret scripture, page 1, viewed 06 April 2018, from https://blog.faithlife.com/blog/2013/09/mark-driscoll-on-let-scripture-interpretscripture/.

Editor, 1987, 'special lady', Presbyterian Life, 06 February.

Editor, 1992a, 'Ministers respond...', Presbyterian Life, 05 March, page 5.

Editor, 1992b, 'Shall we say she's the "reverend" Sister Thomson?', Presbyterian Life, May, pp. 1-2.

Holcomb, J., 2014, Influential women of the Reformation, viewed 05 March 2018, from https://www.christianity.coml/church/church-history/influential-womenof-the-reformation.html

Encyclopædia Britannica, sa, Montanism, viewed 05 March 2018, from https://www. britannica.com/topic/Montanism

Jacquet, C.H. Jr. 1978, Women Ministers in 1977, A report of the Office of Research, Evaluation and Planning, National Council of Churches, Ottawa.

Jacquet, C.H. Jr. 1989, Women Ministers in 1986 and 1977. A Ten-year view, Yearbook of American and Canadian churches, Ottawa. 
Jensen, A., 1996, God's self-confident daughters: Early Christianity and the liberation of women, Westminster Press, Louisville, KY.

Kobo, F.A., 2018a, 'Black women's bodies as reformers from the dungeons: The reformation and womanism', HTS Teologiese Studies/ Theological Studies 74(3), 5015. https://doi.org/10.4102/hts.v74i3.5015

Kobo, F.A. 2018b, 'A womanist exposition of pseudo-spirituality and the cry of an oppressed African woman', HTS Teologiese Studies/ Theological Studies 74(1), 4896. https://doi.org/10.4102/hts.v74i1.4896

Majiza, C.M., 2018, 'Celebrating four decades of women in the ordained ministry' Presentation at the UPCSA General Assembly, 11th July 2018 held in Emsen Retreat Centre, Benoni.

Millard, J.A., 1999, Malihambe - Let the Word spread, UNISA Press, Pretoria.

Murray, D.E., 1973, A background study paper for the Ministry Committee of the PCSA, PCSA, Johannesburg.

Presbyterian Church of Southern Africa (PCSA), 1973, 1975, 1980, 1983, 1987, 1990 1991, 1999, Papers and proceedings of General Assembly, PCSA, Johannesburg.

Presbytery of Tshwane (UPCSA), 2011, Minutes, 14 May, p.3.

Purvis, S.B., 1995, The stained-glass ceiling: Churches and their women pastors, Joh Knox Westminster Press, Louisville, KY.

Reformed Presbyterian Church of Southern Africa (RPCSA) 1979, 1980, 1983,1984, 1985, 1988, 1995, 1996, 1997, 1999, Proceedings of General Assembly, RPCSA, Umtata.

Russell, L.M. (ed.), 1985, Feminist interpretation of the Bible, Westminster Press, Louisville, KY.
Shepherd, R.H.W., 1971, Lovedale, South Africa: 1824-1955, Lovedale Press, Lovedale. Schrage, W., 1988, The ethics of the New Testament, Fortress, Philadelphia, PA.

Trible, P., 1985, 'Postscript: Jottings on the journey', in L.M. Russell (ed.), Feminist interpretation of the Bible, pp. 147-149, Westminster Press, Louisville, KY.

Uniting Presbyterian Church in Southern Africa (UPCSA), 1999, 2000, 2001, 2002, 2010, Papers and proceedings of General Assembly, UPCSA, Johannesburg.

Uniting Presbyterian Church in Southern Africa (UPCSA), 2007, Manual of Faith and order of the Uniting Presbyterian Church in Southern Africa, UPCSA, Johannesburg.

Van Zyl, H.E., 1985, 'The letters of Jane Elizabeth Waterson, 1866-1905' (book review), Presbyterian Life, 06 January1985, p. 6

Walls, A.F., 1996, The missionary movement in Christian history: Studies in the transmission of faith, T \& T Clark, Edinburgh.

Walls, A.F., 2002, The cross-cultural process in Christian history, T \& T Clark, Edinburgh

Women's Consultation (UPCSA), 2018, 'The Uniting Presbyterian Church in Southern Africa General Assembly Statement on Ministers that are women in the UPCSA
from the Women's Consultation at the 13th General Assembly of the Uniting Presbyterian Church in Southern Africa - July 2018', Emseni Retreat Centre, Benoni.

Wuthnow, R., 2014, Rough country: How Texas became America's most powerful bible-belt state, Princeton University Press, Princeton, NJ.

Zikmund, B.B., 1995, 'Foreword', in S.B. Purvis (ed.), The stained-glass ceiling: Churches and their women pastors, pp. vii-xii, Joh Knox Westminster Press, Louisville, KY. 